\title{
Economic Effect of Language Ability on Income and Employment: The Evidence from China
}

\author{
Lucong Wang ${ }^{1} \&$ Jingchao Dai ${ }^{1}$ \\ ${ }^{1}$ School of Economics, Central University of Finance and Economics, Beijing, China \\ Correspondence: Lucong Wang, School of Economics, Central University of Finance and Economics, Beijing, \\ China. E-mail: wanglucongc@163.com
}

Received: November 17, 2020

Accepted: December 26, 2020

Online Published: January 13, 2021

doi:10.5539/ijbm.v16n2p54

URL: https://doi.org/10.5539/ijbm.v16n2p54

\begin{abstract}
As a tool of communication and a carrier of information, language learning needs to pay the price and cost, language ability is also a form of human capital, which has an impact on income and employment. In order to found the economics effects of language ability, we studied relationship between language ability and income using China Family Panel Studies (CFPS) data from 2010 to 2016. We found that improvement of both Mandarin proficiency and English proficiency can significantly promote the total income and wage income. Considering the missing variables in the model and the endogeneity problem of reverse causality, instrumental variables were used to deal with the endogeneity problem, and the income effect of language ability still existed. From the perspective of the influence mechanism, social capital is an important channel through which language ability affects the total income of employees.
\end{abstract}

Keywords: mandarin proficiency, language ability, social capital

\section{Introduction}

In addition to technology and institutions, language is the third force driving economic growth (Aghion \& Howitt, 2009). Language skills are an important form of human capital that has a positive impact on income. Language knowledge is the accumulation of intellectual capital. Like investments in education and health, it is acquired at a price or cost, and the time and money spent is a special investment in human capital. Once the investment pays off, people have more networking opportunities and better job information. Communicate your strengths and skills better with potential recruiters, and they can earn a higher salary or a better position as a result.

Many domestic and foreign empirical studies have found that language plays an obvious role in improving workers' income. Some literatures have found that mastering a foreign language can help workers increase their income (Paola \& Tansel, 2015). For example, there will be an "income premium" phenomenon of English for countries whose official language is not English (Azametal., 2013; Casale \& Posel, 2011). If the laborers have bilingual ability, so his income will be higher than not bilingual workers (Carliner, 1981). Monolingual competence, such as listening, speaking, reading and writing, which also has a certain effect on income (Canwvale et al., 2001). There are also some literatures that suggest that mastering the popular language of a country can also significantly improve the income of workers. For example, Mandarin in China will increase the income of migrants (Gao and Smyth, 2011).

Much of the past research on the impact of language on income (or labor productivity) has been based on empirical studies of cross-border migration in Europe and the United States. However, linguistic and cultural diversity also exists in China. The relationship between Mandarin and dialects is to some extent similar to that between English and other languages in developed countries. There are 55 ethnic minorities in China and many of them have their own languages. The Chinese government also encourages the use and development of such languages in ethnic minority areas. China has seven dialect areas and hundreds of sub-dialect areas, these dialects are different in grammar, vocabulary rhyme and pronunciation, so people in different dialect areas always have more or less difficulties in communication. People are likely to be unable to understand the dialect spoken in a region a hundred kilometers away from their home, and even the dialects vary from county to county in the same province. Communication barriers may have a negative impact on the efficiency of job hunting, the degree of matching, the range of choices and the work efficiency after entry, thus affecting labor efficiency and 
wages. In particular, with the continuous increase of floating population in China, groups with different dialect backgrounds have been integrated into the city in large Numbers. It is difficult for people to communicate across dialect regions or provinces if dialect is relied on alone. However, mandarin, as a common language, has become more important. As early as 1956, the State Council issued the Directive on the Promotion of Mandarin to promote its use. In this way, people can communicate even if they do not understand a dialect or a minority language that is different from their hometown.

The impact of Mandarin on income mainly includes the following aspects: First, improve the efficiency of job search (Chiswick \& Miller, 2014). Proficiency in Mandarin can help employees better understand their various skills and thus better match their abilities and skills to the job requirements of the employer. In many recruitment processes, employees are also required to use Mandarin, which is more convenient for communication and information transmission faster and more effectively. Second, improve work efficiency (Stohr, 2015). Skilled public language enables employees to communicate better with colleagues, leaders, and customers, thus improving work efficiency. Third, the social network can be expanded, which is increased the opportunities for employees to contact with more groups and classes so as to accumulate more experience, knowledge and skills (Wang et al., 2016). For immigrants, another advantage is that speaking Mandarin helps reduce discrimination against them by local consumers and employers (Gao \& Smyth, 2011). Gao and Smyth (2011) found that Mandarin has a positive impact on the wages of Chinese migrant workers, but they did not compare the income effect of Mandarin with that of English.

In addition to studying the income effect of Mandarin, the income effect of English proficiency is also worth studying. With the continuous popularization of English learning in China, the national English level is also constantly improving. However, there are few literatures to analyze the impact of English ability on income and employment. This paper intends to investigate the influence of language ability on the income of laborers on the basis of previous studies. Specifically, the effects of Mandarin and English ability on the total income and wage income of workers are discussed respectively, and the two language abilities are compared and analyzed under a unified framework. From the perspective of social capital, the paper analyzes its influence mechanism. Furthermore, the effect of language ability on employment is investigated.

\section{Literature Review and Theoretical Mechanism}

This part summarizes the related literature from the following aspects: the influence of dialect and Mandarin on the income of laborers, the influence of foreign language on the income of laborers, and analyzes the influence mechanism of language on the income of laborers.

Some scholars have studied the impact of minority languages (dialects) or general languages (Mandarin) on income (Chiswick \& Miller, 2007). Some literature has found no significant increase in financial returns for those who speak a minority or a majority language, compared with those who speak only a majority language. This may be because they do not speak the popular language as fluently as those who only speak it; Or they say the popular language may have some accents, leading to language discrimination in employment. Pendakur (1998) studied the economic return of minority languages in Canada and found that the return rate of their work was lower than that of workers using the common language. Chen et al. (2014) studied the influence of Shanghai dialect on immigrants, and found that the use of dialects can significantly improve the income of service industries. In addition, the use of spoken dialect will have a significant impact on employment income, but the impact of listening on income is not significant. Gao and Smyth (2011) studied the impact of mandarin as a popular language on the income of Chinese migrants from rural to urban areas, and found that mandarin proficiency can significantly improve their income, while Mandarin has a significant impact on the income of women, but not for men. The literature explains that the possible reason is that women are more involved in occupations with more contact with local people. In other words, industry differences lead to differences in the importance of Mandarin, and some industries are more dependent on mandarin.

Other scholars have studied the influence of foreign languages on the income of workers, and many studies have selected English as the foreign language (Azametal., 2013; Casale \& Posel, 2011; Donado, 2014; Grin, 2001; Isphording, 2013; Levinshon, 2007; Stohr, 2015; Toomet, 2011; Williams, 2011). Most literature finds that workers who speak English are paid more in countries where the official language is not English than those who do not. Azam et al. (2013) found that the "wage premium" for Indian men with advanced English skills was as high as 35\%. Non-immigrant Workers who speak English in South Africa earn 18\% to $44 \%$ more in return than non-english speakers (Levinsohn, 2007). Toomet (2011) found that English speakers in Estonia earn 45\% more than non-English speakers, while the figure in Latvia is as high as $62 \%$. Guo and Sun (2014) investigated the income returns of English-speaking workers in China, and their research subjects were limited to college 
graduates. Liu Quan (2014) also found that the salary of foreign language skilled workers in China was about $69 \%$ higher than that of foreign language unskilled workers.

As for the research on the influence channels of language on the income of laborers, scholars mainly believe that language can increase their income through the channels of human capital, social capital accumulation and obtaining more job opportunities. From the perspective of human capital, Mandarin, as a kind of human capital, has the income effect of human capital, and the level of Mandarin ability will directly affect the income of workers. The study of Mandarin is a personal choice, and the uneven distribution of resources among workers will lead to the difference in the distribution of human capital, and eventually lead to the difference in wages. The phenomenon of "language discrimination" exists in the labor market. The larger the size of the Mandarin group, the more the language communication will become an obstacle for the minority labor force to get jobs. At the same time, Mandarin itself is also a threshold requirement for some occupations such as tourism and service industry, which can only be obtained by the labor force with high mandarin level. From the perspective of social capital, Mandarin can promote the formation and accumulation of people's social capital, thus affecting labor income. Social capital is a kind of collective resources, which can be divided into associative social capital, communicative social capital and connected social capital. It is a "bridge" to provide more opportunities for the labor force. It affects the employment through influencing the flow of labor force, occupation acquisition and development, and finally causes the difference of labor income. Mandarin will affect social capital and thus labor income through the social interaction of labor. First, the strong individual language color in the labor market will lead to non-standard expression, and the difficulty in language communication will lead to transaction failure, which will reduce the accumulation of social capital and increase the cost of labor search. Secondly, Mandarin will bring more communication possibilities and increase the social capital stock of labor force. At the same time, individuals with a high level of Mandarin can receive higher quality education and training to improve their knowledge and skills. At present, there are few literatures to study the influence mechanism of language from the perspective of social capital. This paper will analyze whether social capital plays an intermediary role in the income effect of language, so as to enrich empirical studies in this field.

\section{Variable Selection and Model Specification}

\subsection{Variable Selection}

The data used in this paper are mainly from the national sample of the China Family Panel Studies (CFPS) from 2010 to 2016, which is a biennial follow-up survey conducted by the Chinese Center for Social Science Survey at Peking University. The survey aims to comprehensively reflect the social changes and economic development in China by collecting nationally representative information on villages, families and family members.

\subsubsection{Independent Variables and Dependent Variables}

This paper mainly analyzes the economic effect of language ability on income and employment. The dependent variable is the income and employment status of an individual. Income selects the logarithm of the total income and wage income of an individual, and employment selects whether an individual has a job and whether he or she is engaged in non-agricultural work. The independent variable is mandarin and English proficiency to measure individual language proficiency. The measure of Mandarin proficiency comes from the question "Mandarin Proficiency" in the CFPS questionnaire. The measure of mandarin proficiency is expressed on a scale of 1 to 7 . The higher the level, the stronger the Mandarin proficiency. The measure of English ability comes from the question "English ability" in THE CFPS questionnaire. The measure of English ability is expressed on a scale from 1 to 5. The higher the level is, the stronger the English ability is.

\subsubsection{Control Variables}

The control variables selected in this paper include two levels, namely individual level and regional level. Specifically, at the individual level, the control variables of household head include the individual's gender, age, nationality, marital status, household registration, party membership, social status, years of education, and health level. The reasons for choosing the above control variables are as follows: gender and marriage will affect the individual's risk tolerance and job preference; Age, and the increase in work experience that comes with age, has an impact on income and employment; Whether party members will affect the competitiveness of individual job hunting, thus affecting individual income. In addition, social status, years of education and health level, as the human capital accumulation of individuals, will have an impact on their income and employment. At the regional level the control variables include per capita GDP, the proportion of the financial industry and whether it belongs to the western region. In order to control the differences between regional economic development levels, the per capita GDP of individual provinces and cities was introduced. The proportion of the financial industry in GDP was introduced to control the influence of the development of the financial industry in various regions on 
employment. It also controls whether the individual belongs to the western region (Table 1).

Table 1. Control variables

\begin{tabular}{|c|c|c|}
\hline Level & Var. & Interpretation \\
\hline \multirow{10}{*}{ Individual Level } & Gender & Male for 1 , Female for 0 \\
\hline & Age & Age \\
\hline & $\mathrm{Age}^{2} / 100$ & Age squared divided by 100 \\
\hline & National & Han for 1 , otherwise for 0 \\
\hline & Marriage & get married for 1 , otherwise for 0 \\
\hline & Census Register & Urban resident for 1 , otherwise for 0 \\
\hline & Party Member & Party member for 1 , otherwise for 0 \\
\hline & Social status & On a scale of 1 to 5 , the higher the rank, the higher the status \\
\hline & Education & Years of education \\
\hline & Health & On a scale of 1 to 5 , the higher the level, the higher the level of health \\
\hline \multirow{3}{*}{ Regional Level } & Per capita GDP & Per capita GDP of the province in which families live is logarithmic \\
\hline & Financial industry & The financial sector as a share of GDP in the province where the family located \\
\hline & Western region & Whether the family is located in the Western region \\
\hline
\end{tabular}

\subsubsection{Summary Statistics of the Data}

Table 2 summarizes the descriptive statistical results of urban and rural samples. From the perspective of language ability, the average mandarin proficiency is 3.75 , which is in the middle level from 0 to 7 , indicating that the average Mandarin proficiency of Chinese residents is medium. The English proficiency of Chinese residents is low, with an average of 0.32 , indicating that although English learning is becoming increasingly popular in China, the English proficiency of Chinese residents is still at a low level. From the perspective of employment status, the proportion of working individuals is $69 \%$, among which the proportion of individuals engaged in nonagricultural sectors is $71 \%$, indicating that most of the residents in China have jobs and are engaged in nonagricultural sectors. From the perspective of individual characteristics, the surveyed individuals are mainly male and married, with the han nationality accounting for a very high proportion of $91.56 \%$, which is consistent with the reality of China. Individual party members accounted for $12 \%$ of the total population surveyed, which is relatively low. From the perspective of individual human capital, the average social status of individuals is 2.84 , which is in the middle level, and the average years of education is 10.12 , just exceeding the years of compulsory education, and the overall level of education is still not high. The average health level was 2.82 , in the middle of a scale of 0 to 5 . In addition, from the perspective of control variables at the regional level, the average logarithm of per capita GDP is 10.18 , the average ratio of financial industry to GDP is 5.15 , and $32 \%$ of individuals belong to the western region.

Table 2. Summary statistics

\begin{tabular}{lllll}
\hline Var. & Mean & Std. Dev & Min & Max \\
Mandarin proficiency & 3.75 & 2.33 & 0.00 & 7.00 \\
English proficiency & 0.32 & 0.69 & 0.00 & 5.00 \\
Employment & 0.69 & 0.46 & 0.00 & 1.00 \\
Nonagriculture Sectors & 0.71 & 0.45 & 0.00 & 1.00 \\
Gender & 0.68 & 0.47 & 0.00 & 1.00 \\
Age & 51.38 & 12.56 & 16.00 & 97.00 \\
Age ${ }^{2} / 100$ & 27.98 & 13.34 & 2.56 & 94.09 \\
National & 91.56 & 0.28 & 0.00 & 1.00 \\
Marriage & 0.89 & 0.32 & 0.00 & 1.00 \\
Census Register & 0.29 & 0.45 & 0.00 & 1.00 \\
Party Member & 0.12 & 0.33 & 0.00 & 1.00 \\
Social status & 2.84 & 1.04 & 0.00 & 5.00 \\
Education & 10.12 & 4.09 & 0.00 & 21.00 \\
Health & 2.82 & 1.31 & 1.00 & 5.00 \\
Per capita GDP & 10.18 & 0.62 & 8.88 & 11.78 \\
Financial industry & 5.15 & 2.68 & 1.96 & 17.06 \\
Western region & 0.32 & 0.47 & 0.00 & 1.00 \\
\hline
\end{tabular}




\subsection{Model Specification}

\subsubsection{Language Proficiency and Income}

In this subsection, we try to analysis the relationship between income and language ability using the following panel regression model:

$$
w_{i j t}=\beta_{0}+\beta_{1} \text { Language }_{i j t}+\beta_{2} \text { Individual }_{i j t}+\beta_{3} \text { provcd }_{j t}+\mu_{i j t}
$$

$w_{i j t}$ represents the income of an individual, which is divided into total income level and wage

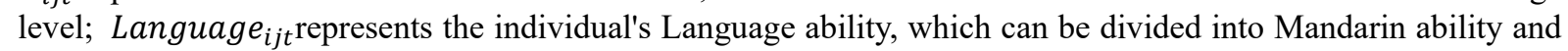
English ability. Individual ${ }_{i j t}$ represents the control variables at the Individual level, $\operatorname{provcd}_{j t}$ represents a locale-level control variable,

$\mu_{i j t}$ is a random disturbance term. In order to reduce the problem of missing variables caused by industry differences, this part controls virtual variables at the industry level. At the same time, in order to reduce the risk of missing variables caused by the differences in cultural traditions and customs among provinces, this paper also controlled the provincial dummy variables, in addition to controlling the year fixed effect.

\subsubsection{Language Proficiency and Employee}

In this part, Probit model is used to study the impact of language ability on individual employment, because whether or not one is employed and whether one is engaged in nonagricultural sector are dummy variables. There is a latent variable $y^{*}$ in the Probit model, when $y^{*}>$ is 0 , the interpreted variable takes the value of 1 , otherwise it takes the value of 0 . The expressions of latent variables and benchmark models in this part are as follows:

$$
\begin{gathered}
y_{i j t}^{*}=\beta_{0}+\beta_{1} \text { Language }_{i j t}+\beta_{2} \text { Individual }_{i j t}+\beta_{3} \text { provcd }_{j t}+\mu_{i j t} \\
\operatorname{Pr}\left(Y_{i j t}=1\right)=\operatorname{Pr}\left(y_{i j t}^{*}>0\right)=\phi\left(\beta_{0}+\beta_{1} \text { Language }_{i j t}+\beta_{2} \text { Individual }_{i j t}+\beta_{3} \text { provcd }_{j t}\right)
\end{gathered}
$$

$Y_{i j t}$ indicates whether family $i$ in district $j$ has employee or engaged in nonagricultural in year $t$. Other variables have the same meaning as model (1). The model also controlled for industry, province, and year fixed effects.

\section{Panel Regression Results}

\subsection{Baseline Regression Results}

\subsubsection{Mandarin Proficiency and Income Analysis}

In this subsection, we estimated results of the correlation between mandarin proficiency and income, which are shown in the Table 3. Table 3 reports the impact of Mandarin proficiency on total income and wage income, in which industry, province and year fixed effects are added in the latter two columns. The first column of Table 3 is the regression result of the influence of Mandarin proficiency on individual total income. The results showed that the regression coefficient of Mandarin proficiency on the logarithm of total income was 0.0403 , which was statistically significant, indicating that the improvement of Mandarin proficiency would have a significant promoting effect on individual total income. The second is the regression result of Mandarin proficiency on individual wage income. The results showed that the regression coefficient of Mandarin proficiency on the logarithm of wage income was 0.0187 , which was also statistically significant, indicating that the improvement of Mandarin proficiency would have a significant promotion effect on individual wage income. The latter two columns controlled for the fixed effect of industry, province and year, and found that the mandarin proficiency still had a significant promoting effect on the total income and wage income, with coefficients of 0.0292 and 0.0156 , respectively, and the values were reduced. 
Table 3. Income effect of Mandarin proficiency analysis

\begin{tabular}{|c|c|c|c|c|}
\hline Depn. & (1) & (2) & (3) & (4) \\
\hline Var. & Total Income & Wage Income & Total Income. & Wage Income \\
\hline \multirow[t]{2}{*}{ Mandarin proficiency } & $0.0403 * * *$ & $0.0187 * * *$ & $0.0292 * * *$ & $0.0156 * * *$ \\
\hline & $(0.0030)$ & $(0.0048)$ & $(0.0033)$ & $(0.0053)$ \\
\hline \multirow[t]{2}{*}{ Gender } & -0.0177 & 0.00718 & $-0.0381 * * *$ & $0.0453^{*}$ \\
\hline & $(0.0137)$ & $(0.0267)$ & $(0.0137)$ & $(0.0267)$ \\
\hline \multirow[t]{2}{*}{ Age } & $0.0196 * * *$ & $-0.0581 * * *$ & $0.0204 * * *$ & $-0.0512 * * *$ \\
\hline & $(0.0033)$ & $(0.0065)$ & $(0.0033)$ & $(0.0065)$ \\
\hline \multirow[t]{2}{*}{$\mathrm{Age}^{2} / 100$} & $-0.0199 * * *$ & $0.0621 * * *$ & $-0.0192 * * *$ & $0.0517 * * *$ \\
\hline & $(0.0032)$ & $(0.0063)$ & $(0.0031)$ & $(0.0063)$ \\
\hline \multirow[t]{2}{*}{ National } & $0.0820^{* * *}$ & $0.106^{* *}$ & 0.0256 & $0.109 * *$ \\
\hline & $(0.0271)$ & $(0.0456)$ & $(0.0278)$ & $(0.0449)$ \\
\hline \multirow[t]{2}{*}{ Marriage } & $-0.0684 * * *$ & $-0.103 * * *$ & $-0.0576 * * *$ & $-0.110 * * *$ \\
\hline & $(0.0204)$ & $(0.0367)$ & $(0.0202)$ & $(0.0363)$ \\
\hline \multirow[t]{2}{*}{ Census Register } & $0.626^{* * *}$ & $0.335^{* * *}$ & $0.594 * * *$ & $0.357 * * *$ \\
\hline & $(0.0148)$ & $(0.0294)$ & $(0.0151)$ & $(0.0317)$ \\
\hline \multirow[t]{2}{*}{ Party Member } & $0.173 * * *$ & $0.120 * * *$ & $0.172 * * *$ & $0.147 * * *$ \\
\hline & $(0.0183)$ & $(0.0314)$ & $(0.0184)$ & $(0.0310)$ \\
\hline \multirow[t]{2}{*}{ Social status } & $0.0644 * * *$ & 0.00409 & $0.0645 * * *$ & -0.000366 \\
\hline & $(0.0061)$ & $(0.0112)$ & $(0.0061)$ & $(0.0112)$ \\
\hline \multirow[t]{2}{*}{ Education } & $0.0578 * * *$ & $0.00962 * * *$ & $0.0558 * * *$ & $0.0143 * * *$ \\
\hline & $(0.0017)$ & $(0.0035)$ & $(0.0017)$ & $(0.0036)$ \\
\hline \multirow[t]{2}{*}{ Health } & $-0.0309 * * *$ & $0.0200 * *$ & $-0.0315 * * *$ & 0.00848 \\
\hline & $(0.0057)$ & $(0.0092)$ & $(0.0057)$ & $(0.0092)$ \\
\hline \multirow[t]{2}{*}{ Per capita GDP } & $0.0492 * *$ & -0.0109 & $-0.959 * * *$ & $3.542 * * *$ \\
\hline & $(0.0236)$ & $(0.0420)$ & $(0.2050)$ & $(0.7320)$ \\
\hline \multirow[t]{2}{*}{ Financial industry } & $0.0701 * * *$ & $0.0335 * * *$ & -0.0111 & 0.0194 \\
\hline & $(0.0039)$ & $(0.0083)$ & $(0.0123)$ & $(0.0407)$ \\
\hline \multirow[t]{2}{*}{ Western region } & $-0.241 * * *$ & $-0.0883 * *$ & $-2.827 * * *$ & $6.021 * * *$ \\
\hline & $(0.0224)$ & $(0.0439)$ & $(0.4030)$ & $(1.3840)$ \\
\hline \multirow[t]{2}{*}{ Constant } & $6.448 * * *$ & $7.325 * * *$ & $18.64 * * *$ & $-31.19 * * *$ \\
\hline & $(0.2410)$ & $(0.4450)$ & $(2.2650)$ & $(8.0180)$ \\
\hline Industry fixed effect & $\mathrm{N}$ & $\mathrm{N}$ & $\mathrm{Y}$ & $\mathrm{Y}$ \\
\hline Province fixed effect & $\mathrm{N}$ & $\mathrm{N}$ & $\mathrm{Y}$ & $\mathrm{Y}$ \\
\hline Year fixed effect & $\mathrm{N}$ & $\mathrm{N}$ & $\mathrm{Y}$ & $\mathrm{Y}$ \\
\hline
\end{tabular}

Note. Robust standard errors are in parentheses. The *,**, and *** indicate statistics significance at $10 \%, 5 \%$, and $1 \%$ levels.

\subsubsection{Income Effect Analysis of English Proficiency}

Next we move forward to the estimated of the correlation between English proficiency and income. Table 4 shows the impact of English proficiency on total income and wage income, with industry, province and year fixed effects added in the latter two columns. The first column of Table 4 is the regression result of the influence of English proficiency on individual total income. The results showed that the regression coefficient of English level on the logarithm of total income was 0.586 , which was statistically significant, indicating that the improvement of English level would have a significant promotion effect on individual total income. The second is the regression result of English proficiency on individual wage income. The results show that the regression coefficient of English proficiency on the logarithm of wage income is 0.199 , which is also statistically significant, indicating that the improvement of English proficiency will have a significant promotion effect on individual wage income. The latter two columns control the fixed effects of industry, province and year, and find that English level still has a significant promotion effect on total income and wage income, with coefficients of 0.275 and 0.214 respectively. Compared with the income effect of Putonghua proficiency, English ability has a greater influence on the total income and salary income, indicating that the improvement of English ability has a stronger promoting effect on income. 
Table 4. Income effect of English proficiency analysis

\begin{tabular}{|c|c|c|c|c|}
\hline Depn. & (1) & (2) & (3) & (4) \\
\hline Var: & Total Income & Wage Income & Total Income. & Wage Income \\
\hline \multirow[t]{2}{*}{ Mandarin proficiency } & $0.586^{* * *}$ & $0.199 *$ & $0.275^{*}$ & $0.214 *$ \\
\hline & $(0.0206)$ & $(0.0105)$ & $(0.0202)$ & $(0.0100)$ \\
\hline \multirow[t]{2}{*}{ Gender } & 0.00684 & $-0.262 * * *$ & $-0.111 * * *$ & $-0.215^{* * *}$ \\
\hline & $(0.0337)$ & $(0.0194)$ & $(0.0338)$ & $(0.0190)$ \\
\hline \multirow[t]{2}{*}{ Age } & $0.0496 * * *$ & $-0.0432 * * *$ & $0.0446^{* * *}$ & $-0.0418 * * *$ \\
\hline & $(0.0079)$ & $(0.0040)$ & $(0.0077)$ & $(0.0040)$ \\
\hline \multirow[t]{2}{*}{$\mathrm{Age}^{2} / 100$} & $-0.0451 * * *$ & $0.0555 * * *$ & $-0.0331 * * *$ & $0.0509 * * *$ \\
\hline & $(0.0075)$ & $(0.0038)$ & $(0.0073)$ & $(0.0038)$ \\
\hline \multirow[t]{2}{*}{ National } & $0.117 * *$ & $0.0796 * * *$ & 0.0291 & $0.0896 * * *$ \\
\hline & $(0.0473)$ & $(0.0265)$ & $(0.0455)$ & $(0.0265)$ \\
\hline \multirow[t]{2}{*}{ Marriage } & $-0.0941 * *$ & $-0.0520 * *$ & -0.0569 & $-0.0694 * * *$ \\
\hline & $(0.0474)$ & $(0.0262)$ & $(0.0459)$ & $(0.0255)$ \\
\hline \multirow[t]{2}{*}{ Census Register } & $0.638 * * *$ & $0.339 * * *$ & $0.522 * * *$ & $0.369 * * *$ \\
\hline & $(0.0329)$ & $(0.0191)$ & $(0.0325)$ & $(0.0200)$ \\
\hline \multirow[t]{2}{*}{ Party Member } & $0.121 * * *$ & -0.00382 & $0.0796^{*}$ & $0.0451 * *$ \\
\hline & $(0.0409)$ & $(0.0224)$ & $(0.0412)$ & $(0.0223)$ \\
\hline \multirow[t]{2}{*}{ Social status } & $0.0460 * * *$ & $-0.0159 * *$ & $0.0575 * * *$ & $-0.0158^{* *}$ \\
\hline & $(0.0134)$ & $(0.0068)$ & $(0.0131)$ & $(0.0067)$ \\
\hline \multirow[t]{2}{*}{ Education } & $0.0676^{* * *}$ & $-0.00426^{* *}$ & $0.0609^{* * *}$ & -0.000262 \\
\hline & $(0.0039)$ & $(0.0020)$ & $(0.0039)$ & $(0.0020)$ \\
\hline \multirow[t]{2}{*}{ Health } & $-0.0296^{* *}$ & $0.0330 * * *$ & $-0.0233^{*}$ & $0.0257 * * *$ \\
\hline & $(0.0122)$ & $(0.0060)$ & $(0.0119)$ & $(0.0059)$ \\
\hline \multirow[t]{2}{*}{ Per capita GDP } & 0.0627 & 0.00322 & $5.262 * * *$ & $1.656^{* * *}$ \\
\hline & $(0.0482)$ & $(0.0245)$ & $(1.2080)$ & $(0.4320)$ \\
\hline \multirow[t]{2}{*}{ Financial industry } & $0.0519^{* * *}$ & 0.00429 & $-0.539 * * *$ & $-0.188^{* * *}$ \\
\hline & $(0.0092)$ & $(0.0053)$ & $(0.1410)$ & $(0.0472)$ \\
\hline \multirow[t]{2}{*}{ Western region } & $-0.127^{* * *}$ & 0.00615 & $2.283^{* * *}$ & $0.548 * *$ \\
\hline & $(0.0462)$ & $(0.0233)$ & $(0.5530)$ & $(0.2160)$ \\
\hline \multirow[t]{2}{*}{ Constant } & $5.751 * * *$ & -0.0241 & $-43.70 * * *$ & $-15.42 * * *$ \\
\hline & $(0.5160)$ & $(0.2650)$ & $(11.4600)$ & $(4.1180)$ \\
\hline Industry fixed effect & $\mathrm{N}$ & $\mathrm{N}$ & $\mathrm{Y}$ & $\mathrm{Y}$ \\
\hline Province fixed effect & $\mathrm{N}$ & $\mathrm{N}$ & $\mathrm{Y}$ & $\mathrm{Y}$ \\
\hline Year fixed effect & $\mathrm{N}$ & $\mathrm{N}$ & $\mathrm{Y}$ & $\mathrm{Y}$ \\
\hline
\end{tabular}

Note. Robust standard errors are in parentheses. The ${ }^{*},{ }^{* *}$, and ${ }^{* * *}$ indicate statistics significance at $10 \%, 5 \%$, and $1 \%$ levels.

\subsection{Endogeneity Analysis}

In most of the literature on the influence of language on income, the endogeneity of language has been considered. According to previous studies of language on income, endogeneity mainly comes from the following two aspects: first, the problem of missing variables, such as the unobservable heterogeneity at the level of individuals, families and regions, will affect the individual's language ability and income at the same time, resulting in biased regression results. Second, the problem of reverse causality, such as the ability of high-income people to invest more human capital to improve their language ability, in addition, high-income people can improve their language ability through more extensive social activities. One solution is to find appropriate instrumental variables for the language. Instrumental variables can basically solve the two possible problems mentioned above. The principle of selecting instrumental variables is that instrumental variables should be directly related to language, but not directly related to income. According to the CFPS questionnaire, the following variables were selected as instrumental variables of Putonghua proficiency: whether the language used during the interview was Putonghua and the average mandarin proficiency in the region where the individual lived; Select the following variables as instrumental variables for English proficiency: average English proficiency in the area.

Table 5 shows the regression results of the instrumental variables. It can be seen that the positive impact of mandarin and English proficiency on income is still significant. This solves the endogeneity problem in the model to some extent and further proves the accuracy of the baseline regression results. 
Table 5. Endogeneity analysis: 2SLS

\begin{tabular}{|c|c|c|c|c|c|c|}
\hline Depn. & (1) & (2) & (3) & (4) & (5) & $(6)$ \\
\hline Var. & Total Income & Wage Income & Total Income. & Wage Income & Total Income. & Wage Income \\
\hline \multirow[t]{2}{*}{ Mandarin proficiency } & $0.0249 * * *$ & $0.0146^{*}$ & $0.0396 * * *$ & $0.0101^{*}$ & & \\
\hline & $(0.0075)$ & $(0.0075)$ & $(0.0054)$ & $(0.0093)$ & & \\
\hline \multirow[t]{2}{*}{ English proficiency } & & & & & $0.247 * * *$ & $0.197 * * *$ \\
\hline & & & & & $(0.0814)$ & $(0.0445)$ \\
\hline \multirow[t]{2}{*}{ Gender } & $-0.0458 * * *$ & $-0.0368 * *$ & $-0.0384 * * *$ & $0.0451 *$ & $-0.103 * * *$ & $-0.207 * * *$ \\
\hline & $(0.0166)$ & $(0.0186)$ & $(0.0137)$ & $(0.0267)$ & $(0.0340)$ & $(0.0194)$ \\
\hline \multirow[t]{2}{*}{ Age } & $0.0339 * * *$ & $-0.0487 * * *$ & $0.0210 * * *$ & $-0.0515 * * *$ & $0.0581 * * *$ & $-0.0295 * * *$ \\
\hline & $(0.0041)$ & $(0.0048)$ & $(0.0033)$ & $(0.0065)$ & $(0.0093)$ & $(0.0049)$ \\
\hline \multirow[t]{2}{*}{$\mathrm{Age}^{2} / 100$} & $-0.0305 * * *$ & $0.0535^{* * *}$ & $-0.0194 * * *$ & $0.0520 * * *$ & $-0.0439 * * *$ & $0.0409 * * *$ \\
\hline & $(0.0039)$ & $(0.0047)$ & $(0.0031)$ & $(0.0063)$ & $(0.0084)$ & $(0.0045)$ \\
\hline \multirow[t]{2}{*}{ National } & 0.0304 & $0.0586^{* *}$ & 0.0249 & $0.108^{* *}$ & 0.026 & $0.0868 * * *$ \\
\hline & $(0.0389)$ & $(0.0284)$ & $(0.0278)$ & $(0.0448)$ & $(0.0458)$ & $(0.0269)$ \\
\hline \multirow[t]{2}{*}{ Marriage } & $-0.0834 * * *$ & $-0.0977 * * *$ & $-0.0578 * * *$ & $-0.111 * * *$ & -0.0469 & $-0.0602 * *$ \\
\hline & $(0.0244)$ & $(0.0263)$ & $(0.0202)$ & $(0.0362)$ & $(0.0459)$ & $(0.0259)$ \\
\hline \multirow[t]{2}{*}{ Census Register } & $0.619^{* * *}$ & $0.272 * * *$ & $0.588 * * *$ & $0.360 * * *$ & $0.476 * * *$ & $0.327 * * *$ \\
\hline & $(0.0190)$ & $(0.0202)$ & $(0.0153)$ & $(0.0322)$ & $(0.0368)$ & $(0.0224)$ \\
\hline \multirow[t]{2}{*}{ Party Member } & $0.153 * * *$ & 0.0359 & $0.169 * * *$ & $0.147 * * *$ & 0.0634 & 0.0301 \\
\hline & $(0.0228)$ & $(0.0235)$ & $(0.0184)$ & $(0.0309)$ & $(0.0416)$ & $(0.0229)$ \\
\hline \multirow[t]{2}{*}{ Social status } & $0.0493 * * *$ & -0.00936 & $0.0644 * * *$ & -0.000279 & $0.0485^{* * *}$ & $-0.0241 * * *$ \\
\hline & $(0.0074)$ & $(0.0074)$ & $(0.0061)$ & $(0.0112)$ & $(0.0135)$ & $(0.0070)$ \\
\hline \multirow[t]{2}{*}{ Education } & $0.0553 * * *$ & 0.0005 & $0.0553 * * *$ & $0.0146^{* * *}$ & $0.0555^{* * *}$ & $-0.00526 * *$ \\
\hline & $(0.0022)$ & $(0.0024)$ & $(0.0017)$ & $(0.0036)$ & $(0.0044)$ & $(0.0023)$ \\
\hline \multirow[t]{2}{*}{ Health } & $-0.0195 * * *$ & $0.0111 *$ & $-0.0309 * * *$ & 0.00827 & $-0.0213 *$ & $0.0276 * * *$ \\
\hline & $(0.0066)$ & $(0.0067)$ & $(0.0057)$ & $(0.0092)$ & $(0.0119)$ & $(0.0060)$ \\
\hline \multirow[t]{2}{*}{ Per capita GDP } & $-1.087 * * *$ & $1.237 *$ & $-0.939 * * *$ & $3.538 * * *$ & $4.979 * * *$ & $1.395 * * *$ \\
\hline & $(0.3530)$ & $(0.7430)$ & $(0.2050)$ & $(0.7300)$ & $(1.2280)$ & $(0.4610)$ \\
\hline \multirow[t]{2}{*}{ Financial industry } & $-0.0389 * *$ & -0.0398 & -0.00984 & 0.0183 & $-0.506 * * *$ & $-0.158 * * *$ \\
\hline & $(0.0156)$ & $(0.0347)$ & $(0.0123)$ & $(0.0406)$ & $(0.1430)$ & $(0.0492)$ \\
\hline \multirow[t]{2}{*}{ Western region } & $-3.273 * * *$ & 1.558 & $-2.757 * * *$ & $5.991 * * *$ & $2.180 * * *$ & $0.454 * *$ \\
\hline & $(0.6640)$ & $(1.2840)$ & $(0.4050)$ & $(1.3790)$ & $(0.5610)$ & $(0.2270)$ \\
\hline \multirow[t]{2}{*}{ Constant } & $21.17 * * *$ & -4.828 & $18.32 * * *$ & $-31.08 * * *$ & $-41.40 * * *$ & $-13.32 * * *$ \\
\hline & $(4.1140)$ & $(8.3790)$ & $(2.2700)$ & $(7.9930)$ & $(11.6400)$ & $(4.3880)$ \\
\hline Industry fixed effect & $\mathrm{Y}$ & $\mathrm{Y}$ & $\mathrm{Y}$ & $\mathrm{Y}$ & Y & $\mathrm{Y}$ \\
\hline Province fixed effect & $\mathrm{Y}$ & $\mathrm{Y}$ & $\mathrm{Y}$ & $\mathrm{Y}$ & $\mathrm{Y}$ & $\mathrm{Y}$ \\
\hline Year fixed effect & $\mathrm{Y}$ & $\mathrm{Y}$ & $\mathrm{Y}$ & $\mathrm{Y}$ & $\mathrm{Y}$ & $\mathrm{Y}$ \\
\hline
\end{tabular}

Note. Robust standard errors are in parentheses. The *,**, and *** indicate statistics significance at $10 \%, 5 \%$, and $1 \%$ levels.

\subsection{Mechanism Analysis}

According to the above analysis, language ability will improve the income level of workers by improving their social capital accumulation. To verify the above logic, we first verify the first link that affects the channel: language ability will promote the accumulation of social capital. Social capital is expressed in terms of the number and popularity of an individual's social activities. Table 6 shows the results of the influence of language ability on social capital. It can be found that the improvement of Mandarin can significantly increase social activities and popularity, which confirms the existence of the first link of the influence mechanism. Table 7 shows the impact of social capital on the total income and wage income. It can be seen that social activities and popularity have a significant positive impact on total income, but not significant impact on wage income. It shows that social capital, as an intermediary variable, becomes the channel through which language ability affects income level, but not the channel through which limited language ability affects wage income.

Table 6. Language ability and social capital analysis

\begin{tabular}{ccc}
\hline Var. & $(1)$ & $(2)$ \\
& Social activities & Popularity \\
\hline Mandarin proficiency & $0.0061^{* *}$ & $0.0083^{*}$ \\
& $(0.0044)$ & $(0.0182)$ \\
Industry fixed effect & $\mathrm{Y}$ & $\mathrm{Y}$ \\
Province fixed effect & $\mathrm{Y}$ & $\mathrm{Y}$ \\
Year fixed effect & $\mathrm{Y}$ & $\mathrm{Y}$ \\
\hline
\end{tabular}

Note. Robust standard errors are in parentheses. The ***, and *** indicate statistics significance at $10 \%, 5 \%$, and $1 \%$ levels. 
Table 7. Social capital and income analysis

\begin{tabular}{lll}
\hline \multirow{2}{*}{ Var. } & $(1)$ & $(2)$ \\
& Total income & Wage income \\
\hline Social activities & $0.0082^{* *}$ & -0.003 \\
& $(0.0049)$ & $(0.0294)$ \\
Popularity & $0.0053^{*}$ & 0.0006 \\
& $(0.0056)$ & $(0.0231)$ \\
Industry fixed effect & $\mathrm{Y}$ & $\mathrm{Y}$ \\
Province fixed effect & $\mathrm{Y}$ & $\mathrm{Y}$ \\
Year fixed effect & $\mathrm{Y}$ & $\mathrm{Y}$ \\
\hline
\end{tabular}

Note. Robust standard errors are in parentheses. The *,**, and *** indicate statistics significance at $10 \%, 5 \%$, and $1 \%$ levels.

\subsection{Mandarin Proficiency and Employment Analysis}

In this part, we analyze the effect of language ability on employment (Table 8). Table 8 shows the influence of Mandarin proficiency on employment and nonagricultural sector employment in which industry, province and year fixed effects are added in the latter two columns. The first column of Table 8 is the regression result of the influence of Mandarin proficiency on whether an individual has a job or not. The results showed that the regression coefficient of Mandarin proficiency on individual work was 0.0058 , which was statistically significant, indicating that the improvement of Mandarin proficiency would have a significant promotion effect on individual employment. The second is the regression result of Mandarin proficiency on individual nonagricultural employment. The results show that the regression coefficient of Mandarin level on nonagricultural employment is 0.0175 , which is also statistically significant, indicating that the improvement of Mandarin level will have a significant promoting effect on individual nonagricultural sector employment. The latter two columns control the fixed effect of industry, province and year, and find that mandarin level still has a significant promoting effect on individual nonagricultural sector employment, with a coefficient of 0.0089 , respectively, but no longer has a significant influence on individual employment.

Table 8. Mandarin proficiency and employment analysis

\begin{tabular}{lllll}
\hline Depn. & $(1)$ & $(2)$ & $(3)$ & $(4)$ \\
Var. & Employment & Nonagricultural Sector & Employment & Nonagricultural Sector \\
\hline Mandarin proficiency & $0.0058^{* * *}$ & $0.0175^{* * *}$ & -0.0008 & $0.0089^{* * * *}$ \\
& $(0.0049)$ & $(0.0044)$ & $(0.0060)$ & $(0.0061)$ \\
Gender & $0.1026^{* * *}$ & $-0.194^{* * *}$ & $0.570^{* * *}$ & $-0.173^{* * *}$ \\
& $(0.0233)$ & $(0.0218)$ & $(0.0266)$ & $(0.0270)$ \\
Age & $0.0269^{* * *}$ & $-0.0903^{* * *}$ & $0.130^{* * *}$ & $-0.127^{* * *}$ \\
& $(0.0063)$ & $(0.0060)$ & $(0.0070)$ & $(0.0074)$ \\
Age $/ 100$ & $-0.145^{* * *}$ & $0.0846^{* * *}$ & $-0.166^{* * *}$ & $0.125^{* * *}$ \\
& $(0.0062)$ & $(0.0058)$ & $(0.0069)$ & $(0.0070)$ \\
National & $-0.826^{* * *}$ & $0.501^{* * *}$ & $-0.666^{* * *}$ & $0.241^{* * *}$ \\
& $(0.0258)$ & $(0.0248)$ & $(0.0492)$ & $(0.0523)$ \\
Marriage & $0.0869^{* *}$ & $-0.184^{* * *}$ & $0.150^{* * *}$ & $-0.215^{* * *}$ \\
& $(0.0360)$ & $(0.0342)$ & $(0.0390)$ & $(0.0412)$ \\
Census Register & $-0.772^{* * * *}$ & $1.205^{* * *}$ & $-0.770^{* * *}$ & $1.597 * * *$ \\
& $(0.0292)$ & $(0.0319)$ & $(0.0326)$ & $(0.0401)$ \\
Party Member & $0.261^{* * *}$ & $0.236^{* * *}$ & $0.2433^{* * *}$ & $0.206^{* * *}$ \\
& $(0.0377)$ & $(0.0358)$ & $(0.0413)$ & $(0.0430)$ \\
Social status & $0.0823^{* * *}$ & $-0.0470^{* * *}$ & $0.0479^{* * *}$ & $-0.0534^{* * *}$ \\
& $(0.0100)$ & $(0.0092)$ & $(0.0110)$ & $(0.0115)$ \\
Education & $0.0148^{* * *}$ & $0.0198^{* * *}$ & $0.0152^{* * *}$ & $0.0216^{* * *}$ \\
& $(0.0031)$ & $(0.0027)$ & $(0.0034)$ & $(0.0034)$ \\
Health & $-0.0755^{* * *}$ & 0.00682 & $-0.0611^{* * *}$ & $0.0395^{* * *}$ \\
& $(0.0091)$ & $(0.0081)$ & $(0.0103)$ & $(0.0103)$ \\
Per capita GDP & $0.195^{* * *}$ & $-0.563^{* * *}$ & $1.388^{* * *}$ & 0.314 \\
& $(0.0433)$ & $(0.0391)$ & $(0.3830)$ & $(0.4860)$ \\
Financial industry & $0.0506^{* * *}$ & $0.385^{* * *}$ & $-0.0918^{* * *}$ & 0.0202 \\
& $(0.0076)$ & $(0.0108)$ & $(0.0223)$ & $(0.0290)$ \\
Western region & $0.124^{* * *}$ & $-0.765^{* * *}$ & $2.208^{* * *}$ & -0.00334 \\
& $(0.0425)$ & $(0.0383)$ & $(0.7730)$ & $(0.2480)$ \\
Constant & 5.275 & $6.645^{* * *}$ & $-16.50^{* * *}$ & 0.233 \\
& $(0.2846)$ & $(0.4040)$ & $(4.2480)$ & $(4.6810)$ \\
Industry fixed effect & $\mathrm{N}$ & $\mathrm{N}$ & $\mathrm{Y}$ & $\mathrm{Y}$ \\
Province fixed effect & $\mathrm{N}$ & $\mathrm{N}$ & $\mathrm{Y}$ & $\mathrm{Y}$ \\
Year fixed effect & $\mathrm{N}$ & $\mathrm{N}$ & $\mathrm{Y}$ & $\mathrm{Y}$ \\
\hline
\end{tabular}

Note. Robust standard errors are in parentheses. The *, **, and *** indicate statistics significance at $10 \%, 5 \%$, and $1 \%$ levels. 


\section{Conclusion}

In this paper, we analyzed the income and employment effects of language proficiency. The results show that the improvement of both Mandarin proficiency and English proficiency can significantly promote the total income and wage income, but the English proficiency is stronger. Considering the missing variables in the model and the endogeneity problem of reverse causality, this part adopts instrumental variables to deal with the endogeneity problem, and finds that the income effect of language ability still exists. From the analysis of the influence mechanism, social capital is an important channel through which language ability affects the total income, but not the wage income. Furthermore, this part analyzes the employment effect of language ability, and finds that the improvement of language ability will have a significant promoting effect on nonagricultural employment. Language is not only a tool for communication, but also has economic value. Analyzing the role of language from the perspective of economy, on the one hand, provides data support for studying the influence of culture on economic growth; on the other hand, the discussion on the influence mechanism of language also enriches the research framework of linguistic economics. And this paper only discusses the impact of language ability on the income and employment of labors from the micro perspective, but as the third major force driving economic growth (Aghion \& Howitt, 2009), language also has a direct impact on macroeconomic development, such as labor mobility, degree of social civilization, innovation and entrepreneurship in counties, urbanization construction, poverty alleviation, etc. Therefore, we should further analyze the economic value of language from a macro perspective to enrich and perfect the research framework of linguistic economics.

\section{References}

Aghion, P., \& Howitt, P. (2009). The Economics of Growth. The MIT Press.

Azam, M., Chin, A., \& Prakash, N. (2013). The Returns to English Language Skills in India. Economic Development and Cultural Change, 61(2), 335-367. https://doi.org/10.1086/668277

Canevale, A., Richard, F., \& Lowell, L. (2001). Understanding, Speaking, Reading, Writing, and Earnings in the Immigrant Labor Market. American Economic Review, 91(2), 159-163. https://doi.org/10.1257/aer.91.2.159

Carliner, G. (1981). Wage Differences by Language Group and the Market for Language Skills in Canada. The Journal of Human Resources, 16(3), 384-399. https://doi.org/10.2307/145627

Casale, D., \& Posel, D. (2011). English Language Proficiency and Earnings in a Developing Country: The Case of South Africa. The Journal of Social Economics, 40(4), 385-393. https://doi.org/10.1016/j.socec.2011.04.009

Chen, Z., Lu, M., \& Xu, L. (2014). Returns to Dialect: Identity Exposure through Language in the Chinese Labor Market. China Economic Review, 30(9), 27-43. https://doi.org/10.1016/j.chieco.2014.05.006

Chiswick, B. R., \& Miller, P. W. (2007). Earnings and Occupational Attainment: Immigrants and the Native Born. Economics Discussion. https://doi.org/10.2139/ssrn.978751

Chiswick, B. R., \& Miller, P. W. (2014). International Migration and the Economics of language. Handbook of the Economics of Immigration, Elsevier. https://doi.org/10.1016/B978-0-444-53764-5.00005-0

Donado, A. (2014). Foreign Languages and Their Impact on Income and Unemployment. Beitrage zur Jahrestagung des Vereins fur Socialpolitik.

Gao, W., \& Smyth, R. (2011). Economic Returns to Speaking "Standard Mandarin" among Migrants in China's Urban Labor Market. Economics of Education Review, 30(2), 342-352. https://doi.org/10.1016/j.econedurev.2010.11.002

Grin, F. (2001). English as Economic Value: Facts and Fallacies. World Englishers, 20(1), 65-78. https://doi.org/10.1111/1467-971X.00196

Guo, Q., \& Sun W. (2014). Economics Returns to English Proficiency for College Graduates in Mainland China. China Economic Review, 30, 290-300. https://doi.org/10.1016/j.chieco.2014.07.014

Isphording, I. E. (2013). Returns to Foreign Language Skills of Immigrants in Spain. Labor, 27(3), 443-461. https://doi.org/10.1111/labr.12020

Levinsohn, J. (2007). Globalization and the Returns to Speaking English in South Africa. In Globalization and Poverty, 629-646. https://doi.org/10.7208/chicago/9780226318004.003.0016

Paolo, A. D., \& Tansel, A. (2015). Returns to Foreign Language Skills in a Developing Country: The Case of $\begin{array}{lllll}\text { Turkey. Journal of Development } & \text { Studies, } & \text { 51(4), } & \text { 407-421. }\end{array}$ 
https://doi.org/10.1080/00220388.2015.1019482

Pendakur, R. (1998). Speak and yes hall Receive: Language Knowledge as Human Capital. Economic Approaches to Language and Bilingualism, 89-121.

Stohr, T. (2015). The Returns to Occupational Foreign Language Use: Evidence from Germany. Labor Economics, 32:86-98. https://doi.org/10.1016/j.labeco.2015.01.004

Toomet, O. (2011). Learn English, not the Local Language! Ethnic Russians in the Baltic States. American Economics Review, 101(3), 526-531. https://doi.org/10.1257/aer.101.3.526

Wang, H., Cheng, Z., \& Smyth, R. (2016). Language and Consumption. China Economic Review, 40(3), 135-151. https://doi.org/10.1016/j.chieco.2016.06.009

Williams, D. (2011). Multiple Language Usage and Earnings in Western Europe. International Journal of Manpower, 32(4), 372-393. https://doi.org/10.1108/01437721111148513

\section{Copyrights}

Copyright for this article is retained by the author(s), with first publication rights granted to the journal.

This is an open-access article distributed under the terms and conditions of the Creative Commons Attribution license (http://creativecommons.org/licenses/by/4.0/). 